\title{
Reaksi Esensial Oil Lavender Pada Recovery Denyut Jantung Atlet Bolavoli
}

\section{Reaction of Lavender Essential Oil on Heart Rate Recovery in Volleyball Athletes}

\author{
Edi Irwanto ${ }^{1}$, Arik Winarto ${ }^{2}$ \\ 1,2 Prodi Pendidikan Jasmani Kesehatan dan Rekreasi, Fakultas Olahraga Kesehatan, Universitas \\ PGRI Banyuwangi, Indonesia \\ e-mail: irwantoedi88@gmail.com ${ }^{1}$, arikwinarto91@gmail.com² \\ doi:https://doi.org/10.20884/1.paju.2021.3.1.4702
}

\begin{abstract}
Abstrak
Aromaterapi merupakan tindakan terapeutik dengan menggunakan minyak essensial yang bermanfaat meningkatkan keadaan fisik dan psikologi seseorang agar menjadi lebih baik. Salah satunya yaitu dengan menggunakan esensial oil lavender. Tujuan peneltian ini adalah untuk mengetahui reaksi pemberian esensial oil lavender pada penurunan denyut nadi pemain bolavoli UNIBAVC. Metode yang digunakan dalam penelitian ini adalah metode eksperimental one group pretest-posttest desaign dengan jumlah sampel 10 pemain. Instrumen penelitian mengunakan pengukuran denyut nadi latihan dan denyut nadi awal pada atlet. Alat dan bahan yang digunakan meliputi esensial oil lavender, Fingertip Pulse Oximeter, Stopowatch. Analisis data dilakukan dengan perhitungan Uji T. Hasil penelitian menunjukan bahwa penggunaan esensial oil lavender dengan cara dioleskan dibagian dada dapat mempercepat recovery denyut nadi pemain bolavoli UNIBAVC dengan nilai signifikansi sebesar 4,49. Kesimpulan dari penelitian ini yaitu penggunaan iol lavender dapat menjadi alternatif yang digunakan pada saat pertandingan untuk mempercepat proses pemulihan (Recovery) atlet, khususnya atlet bolavoli.
\end{abstract}

Kata Kunci: Bolavoli, Esensial Oil Lavender, Denyut Jantung, Recovery

\begin{abstract}
Aromatherapy is a therapeutic action using essential oils that are useful for improving a person's physical and psychological state to become better, one of which is by using lavender essential oil. The purpose of this study was to determine the reaction of giving lavender essential oil on decreasing the pulse rate of UNIBAVC volleyball players. The method used in this study is an experimental method of one group pretest-posttest design with a sample of 10 players. The research instrument uses the measurement of the exercise pulse and initial pulse rate in athletes. The tools and materials used include lavender essential oil, Fingertip Pulse Oximeter, Stopowatch. Analysis was carried out by calculating the $T$ test. The results showed that the use of lavender essential oil by applying it on the chest could accelerate the recovery of the pulse rate of
\end{abstract}

Alamat Koresponden : Prodi Pendidikan Jasmani Kesehatan dan Rekreasi, Fakultas Olahraga Kesehatan, Universitas PGRI Banyuwangi

Email : irwantoedi88@gmail.com

Jurnal Physical Activity Journal (PAJU) This work is licensed under a Creative Commons Attribution 4.0 International License. 
UNIBAVC volleyball players with a significance value of 4.49. The conclusion of this study is that the use of lavender oil can be an alternative used during matches to speed up the recovery process for athletes, especially volleyball athletes.

Keywords: Heart Rate, Lavender Essential Oil, Recovery, Volleyball

\section{PENDAHULUAN}

Olahraga merupakan aktivitas sistem muskula skeletal yang sistematis dan terstruktur dengan frekuensi, intensitas, tipe dan waktu yang telah ditentukan (Wiarto, 2013). Permainan bolavoli adalah suatu bentuk permainan dimainkan oleh dua regu, pada setiap regu berjumlah enam pemain dan dipisahkan oleh sebuah net di tengah lapangan (Irwanto et al., 2021) . Pada permainan bolavoli dibutuhkan kemampuan yang lengkap meliputi kondisi fisik, teknis, mental dan taktis, kondisi fisik pemain memberikan efek yang sangat vital pada keterampilan pemain (Taware et al., 2013) . Untuk dapat menjaga kualitas permainan agar tetap stabil, maka pemain harus dapat memulihkan kondisi fisik atau stamina secepat mungkin pada saat perpindahan set atau ketika duduk dibangku cadangan. Ketika pertandingan memulihkan rasa lelah dari suatu pertandingan ke pertandingan berikutnya mejadi permasalah yang biasa dihadapi pemain.

Dalam pertandingan faktor pemulihan ini memegang peranan yang sangat penting (Arifushalat, 2019). Pemulihan (recovery) adalah mengembalikan kondisi tubuh setelah pertandingan ke keadaan sebelum pertandingan (Purwata, 2015). Untuk mendapatkan pemulihan ketika duduk di bangku cadangan, maka pemain harus diberi perlakukan, sehingga kondisi tubuh pulih, bugar, dan denyut nadi menjadi normal kembali untuk mengikuti pertandingan (Laksana et al., 2019). Denyut nadi adalah perjalanan dari denyut jantung yang dihitung setiap menitnya dengan hitungan repetisi (kali/menit), dengan denyut nadi normal 60-100 kali/menit (Lubis \& Siregar, 2017). Pendapat lain mengatakan bahwa denyut nadi adalah isyarat penting di bidang medis yang memiliki manfaat untuk mengevaluasi dengan cepat kesehatan atau mengetahui kebugaran seseorang secara umum (Tias \& Hidayat, 2018). Recovery denyut nadi yang baik memiliki jumlah denyut nadi dibawah 100 denyut per menit setelah 5 menit (Hafizudin et al., 2018). Denyut jantung dan nadi optimal untuk setiap pemain tergantung pada waktu pengukuran detak jantung tersebut (saat istirahat atau setelah berolahraga). Faktor yang dapat mempengaruhi denyut jantung seseorang, yaitu usia, aktivitas fisik dan tingkat kebugaran, waktu 
Edi Irwanto \& Arik Winarto | Reaksi Esensial Oil Lavender Pada Recovery Denyut Jantung Atlit Bolavoli UNIBAVIC

perhitungan, suhu udara, posisi tubuh (berbaring atau berdiri), tingkat emosi, fluktuasi hormon, asupan kafein, merokok, ukuran tubuh serta obat yang sedang dikonsumsi. Aktivitas fisik dapat meningkatkan jumlah denyut jantung (Mehemed, 2014). Ada beberapa cara yang dilakukan untuk mengembalikan denyut nadi ke keadaaan normal, salah satunya dengan pemberian aroma terapi.

Aroma terapi adalah satu teknik pengobatan atau perawatan menggunakan baubauan yang menggunakan minyak esensial (Prima \& Ap, 2013). Pendapat lain mengatakan bahwa aromaterapi merupakan tindakan terapeutik dengan menggunakan minyak essensial yang bermanfaat meningkatkan keadaan fisik dan psikologi seseorang agar menjadi lebih baik, atau terapi dengan menggunakan bau-bauan yang berasal dari tumbuh-tumbuhan,bunga, pohon, yang berbau harum dan enak (Craig, 2015). Pemberian aromaterapi dengan esensial oil lavender dapat memperpendek waktu pemulihan tekanan darah sistolok dan denyut nadi (Lubis et al., 2009). Aromaterapi menggunakan minyak lavender dipercaya dapat memberikan efek relaksasi bagi saraf dan otot-otot yang tegang (carminative) setelah lelah beraktivitas (Prima \& Ap, 2013).

Pada saat bertanding pemain dituntut untuk mengeluarkan kemampuan maksimal atau permainan terbaiknya untuk dapat memenangkan suatu pertandingan. Apabila terjadi rally panjang pemain harus dapat menjaga kondisi fisiknya agar penampilan tetap terus stabil. Dari keadan tersebut pelatih menggunakan strategi pergantian pemain baik dengan pemain cadangan ataupun libero untuk menjaga kondisi fisik para pemain. Dengan strategi tersebut ada jeda beberapa waktu untuk pemain melakukan recovery ke keadaan semula. Sedangkan recovery kondisi fisik tidak dapat secepat apa yang diharapakan oleh pemain dan pelatih. Oleh sebab itu, dengan bantuan esensial oil lavender diharapakan dapat mempercepat recovery denyut jantung, yang mana dengan semakin cepat recovery denyut jantung, pemain dapat kembali mendapatkan kondisi fisik yang baik seperti semula.

Beberapa hasil penelitian menyatakan bahwa aromaterapi dengan menggunakan minyak esensial lavender dapat menyebabkan penurunan yang bermakna terhadap tekanan darah dan denyut jantung (Wulansari, 2017). Hal ini juga didiukung hasil penelitian (Widiarti \& Suhardi, 2015) yang menyatakan bahwa aroma terapi lavender adalah terapi yang menggunakan minyak enssensial yang dinilai dapat membantu mengurangi bahkan mengatasi gangguan psikologis dan gangguan rasa nyaman seperti cemas, stress, depresi, dan sebagainya. aromaterapi dengan menggunakan minyak esensial lavender 
dapat menyebabkan penurunan yang bermakna terhadap tekanan darah dan denyut jantung (Kholiqoh, 2017).

Pada waktu bertanding pemain mengeluarkan banyak energi dan tenaga yang menyebabkan kecepatan detak jantung bertambah. Dengan semakin bertambahnya detak jantung tersebut menimbulkan efek yaitu kelelahan. Ketika pemain mengalami kelelahan maka berakibat pada penurunan penampilan. Untuk mengantisipasi hal tersebut maka pemain harus dapat mempercepat proses pemulihan. Untuk mempercepat pemulihan agar penampilan tetap stabil, maka pemain harus diistirahatkan. Pada waktu diistirahatkan terjadilah proses pemulihan detak jantung ke posisi normal. Waktu lamanya pemulihan tersebut sangat mempengaruhi penampilan pemain abila pemain tersebut dimainkan kembali. Terkait waktu pemulihan detak jantung apakah efek penggunaan esensial oil lavender berpengaruh terhadap penurunan detak jantung atau denyut nadi, bagaimanakah reaksi pemberian esensial oil lavender pada denyut nadi pemain bolavoli UNIBVC. Tujuan peneltian ini adalah untuk mengetahui reaksi pemberian esensial oil lavender pada penurunan denyut nadi pemain bolavoli UNIBAVC.

\section{METODE}

Metode yang digunakan dalam penelitian ini adalah metode eksperimental one group pretest-posttest desaign. One group pretest-posttest desaign adalah sebuah eksperimen yang memberikan tes awal (pretest) sebelum diberikan perlakuan, setelah diberikan perlakuan kemudian diberikan tes akhir (posttest) sebagai perbandingan hasil perlakuan (Sugiyono, 2013). Pree test dilakukan dengan mengukur waktu pemulihan denyut nadi setelah aktivitas fisik tanpa memberikan esensial oil. Post test dilakukan dengan mengukur waktu pemulihan denyut nadi setelah aktivitas dengan memberikan esensial oil.

Teknik penentuan jumlah sampel menggunakan total sampling yaitu berjumlah 10 pemain. Pengambilan data dilakukan di lapangan bolavoli UNIBAVC. Alat dan bahan yang digunakan meliputi esensial oil lavender, Fingertip Pulse Oximeter, Stopowatch. Pengumpulan data dilakukan dengan dua tahapan, tahap pertama yaitu pengukuran penurunan denyut nadi setelah aktivitas tanpa memberikan esensial oil, dan tahap dua yaitu pengukuran penurunan denyut nadi setelah aktvitas dengan cara memberikan esensial oil. Pemberian esensial oil dilakukan setelah atlet melakukan aktivitas fisik dengan cara mengoleskan langsung kult dada bagian luar (Djilani \& Dicko, 2012). 
Edi Irwanto \& Arik Winarto | Reaksi Esensial Oil Lavender Pada Recovery Denyut Jantung Atlit Bolavoli UNIBAVIC

Prosedur pelaksanaan meliputi: mengukur denyut nadi awal mahasiswa setelah melakukan aktivitas fisik dengan menggunakan intensitas latihan $90 \%$ (ketentuan denyut nadi mencapai 180 bpm) dan mencatat durasi recovery denyut nadi (dari 180 bpm kembali ke denyut nadi awal). Analisis data dilakukan dengan perhitungan Uji T yang disajikan dalam bentuk table dan grafik.

\section{HASIL}

Data dideskripsikan menjadi beberapa tahapan meliputi: tahap pertama (preetest), tahap kedua (posttest). Hasil rata-rata denyut nadi atlet bolavoli dapat dilihat pada tabel 1. dibawah ini:

Tabel 1. Hasil Deskripsi Data Denyut Nadi Atlet Bolavoli

\begin{tabular}{cccc}
\hline Tahapan & $\begin{array}{c}\text { Denyut Nadi Awal } \\
\text { (bpm) }\end{array}$ & $\begin{array}{c}\text { Denyut Nadi Maksimal } \\
\text { (bpm) }\end{array}$ & $\begin{array}{c}\text { Denyut Nadi recovery } \\
\text { (mnt) }\end{array}$ \\
\hline Preetest & 86 & 180 & 6.81 \\
\hline Posttest & 81.81 & 180 & 4.85 \\
\hline
\end{tabular}

Berdasarkan tabel 1 diatas dapat diketahui bahwa dari jumllah sampel 10 pemain didapatkan rata-rata denyut nadi awala sebelum melakukan aktifitas fisik pada tahapan pree test sebesar $86 \mathrm{bpm}$ dan pada tahapan posttest sebesar 81,81. Denyut nadi maksimal (batasan acuan denyut nadi maksimal) sebesar 180 bpm. Rata-rata waktu recovery denyut nadi pada tahapan preetest dari 180 bpm kembali ke 86 bpm sebesar 7 , 05 menit dan pada tahapan posttest sebesar 5,38 menit.

Tahap analisis data berikutnya yaitu dilakukan uji beda dengan menggunakan uji $t$ Tes untuk mengetahui efektivitas pengunaan oil lavender dalam menurunkan denyut nadi recovery atlet bolavoli. Hasil uji analisis data tertera pada Tabel 2 dan Gambar 1 dibawah ini.

Table 2. Hasil Analisis Data

\begin{tabular}{cccc}
\hline $\mathbf{N}$ & $\sum \mathbf{d}$ & $\sum \mathbf{d}^{\mathbf{2}}$ & $\mathbf{T}-$ Test \\
\hline 10 & 21.6 & 67,52 & 4.49 \\
\hline
\end{tabular}

Dari tabel 2. Diatas dapat diketahui bahwa dari jumlah sampel 10 pemain didapatkan nilai $\sum \mathrm{d}$ sebesar 21,6 , nilai $\sum \mathrm{d}^{2}$ sebesar 67,52 , dan perhitungan Uji t sebesar 4,49. Berikut data disajikan dalam bentuk grafik. 


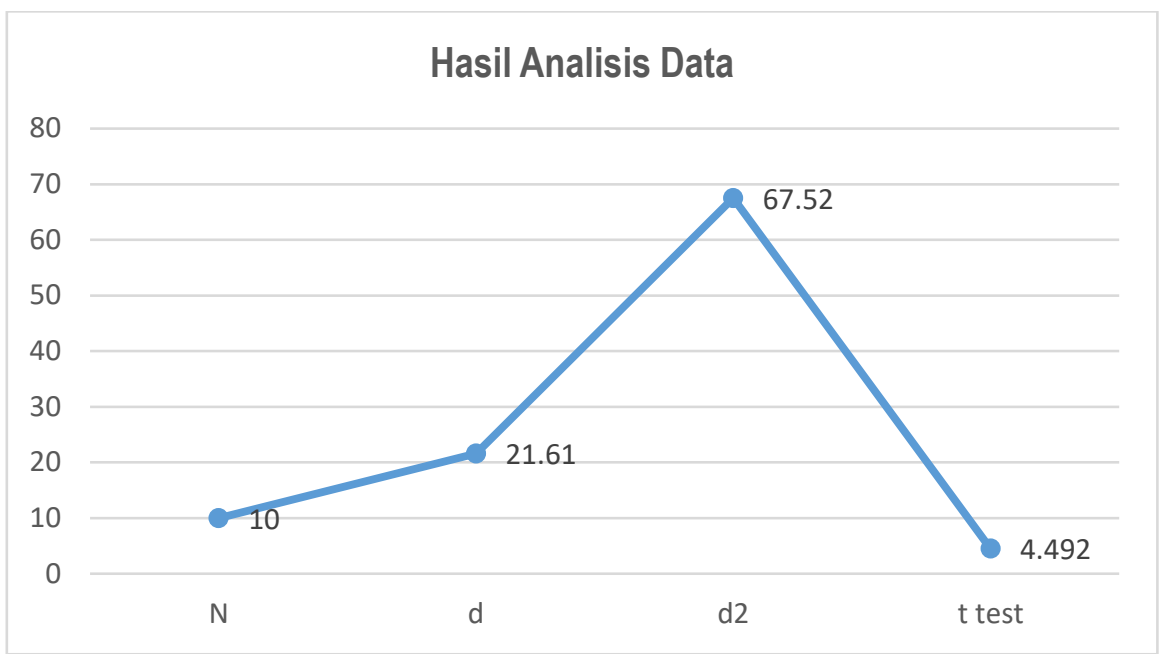

Grafik 1. Hasil analisis data

Dari hasil anaslis data diatas diketahui bahwa nilai t hitung $=4,49>\mathrm{t}$ tabel $=1,833$ pada taraf signifikansi 0,05 . Yang artinya nilai t hitung lebih besar dari nilai t tabel, maka berdasarkan hasil analysis data membuktikan bahwa penggunaan esensial oil lavender secara signifikan mempercepat recovery detak jantung pemain bolavoli UNIBAVC.

\section{PEMBAHASAN}

Berdasarkan hasil analisi data didapatkan hasil bahwa esensial oil lavender secara signifikan dapat mempercepat recovery detak jantung atau denyut nadi. Hal ini dikarenakn esensial oil lavender memiliki kandunga zat yang dapat merelaksasi otak yang dapat meyebabkan pikiran menjadi rileks atau tenang. Esensial oil lavender (Lavandula angustifolia) dapat memberikan efek sedatif karena didalamnya terdapat kandungan aktif utama yaitu linalool (Ramadhan \& Zettira, 2017). Kandungan utama pada minyak ini ialah linalool 26\%-49\% dan linalil asetat. Sifat farmakologi dari esensial oil lavender dapat menimbulkan efek relaksasi yang dipengaruhi oleh linalool dan linalil asetat, efek farmakolgi menimbulkan relaksasi secara fisik ataupun psikologis yang mana salah satunya mempunyai sifat analgesik, dan menenangkan, secara farmakologi esensial oil lavender mempunyai efek terapetik yang dapat mempengaruhi sistem saraf simpatis, parasimpatis dan sistim limbik (Pujiati et al., 2019).

Penggunaan dengan cara dioleskan pada area dada berpengaruh pada proses recovery denyut nadi. Hal ini dikarenakan terjadi dua proses yaitu proses inhalasi dan proses penyerapan langsung melalui kulit. Yang mana pada proses inhalasi aromaterapi ini menyebabkan molekul-molekul pada esensial oil yang terhirup akan terbawa oleh arus 
Edi Irwanto \& Arik Winarto | Reaksi Esensial Oil Lavender Pada Recovery Denyut Jantung Atlit Bolavoli UNIBAVIC

turbulen di hidung. Molekul esensial oil yang tertahan pada bulu-bulu hidung merupakan suatu impuls akan ditransmisikan melalui bulbus olfaktorius dan traktus olfaktorius yang masuk ke dalam sistem limbik (Buckle, 2014). Proses ini akan mendorong memori dan emosi melalui hipotalamus bekerja sebagai pengatur yang dapat mengakibatkan pesan tersebut dikirim ke otak dan bagian tubuh lainnya.

Ada beberapa cara aplikasi aromaterapi secara inhalasi yaitu dengan dituangkan ke kertas tissue, pengusapan langsung ditangan, penggunaan alat penguap/steamer, rendaman, botol penyemprot dan vaporizer/diffuser (Siahaan et al., 2014). Pada proses penyerapan melalui pori-pori pada kulit, esensial oil merupakan zat yang digunakan dalam pengobatan penunjang karena kerutannya dalam lipid yang ditemukan di dalam stratum korneum, yang mana essensial oil ini dipercaya lebih mudah diserap oleh kulit. Proses penyerapan senyawa ini terjadi pada saat melalui lapisan epidermis kulit dan masuk ke saluran limfe, kelenjar keringat, saraf, serta masuk ke dalam aliran darah dan menuju ke setiap sel tubuh untuk bereaksi (Djilani \& Dicko, 2012).

Percepaatan penurunan detak jantung dipengaruhi juga oleh kondisi fisik atau rutinnitas berolahraga. Hal ini sesuai dengan pendapat Reka et al. (2020) yang menyatakan bahwa ada perbedaan recovery detak jantung antara yang rutin beolahraga dan tidak. Peneltian sejenis juga dilakukan oleh Lubis \& Siregar (2017) hasil peneltian menyatakan bahwa kegiatan olahraga dapat mempercepat 1-20 denyut nadi pemulihan permenit. Sehingga recovery denyut jantung akan lebih maksimal apabila didukung oleh aktivitas, latihan, dan kondisi fisik yang baik serta ditambah dengan pemberian stimulan dari esensial oil.

\section{SIMPULAN}

Penggunaan esensial oil lavender dengan cara dioleskan dibagian dada dapat mempercepat recovery denyut nadi pada pemain bolavoli UNIBAVC. Penggunaan esensial oil lavender dapat dilakukan dengan beberapa metode seperti pengolesan langsung, inhalasi, massage. Pada pertandingan bola penggunaan esensial untuk recovery denyut nadi dapat dilakukan pada pergantian pemain (quiker dengan libero) dan juga pada saat perpindahan set dengan cara pengolesan langsung dibagian dada. Dengan cara dioleskan ini secara tidak langsung terjadi dua proses penyerapan yaitu meresap melalui pori-pori kulit dan juga inhalasi (aroma lavender terhirup pada saat bernafas). 


\section{REFERENSI}

Arifushalat. (2019). Pengaruh Recovery Aktif dan Pasif Terhadap Denyut Nadi Pemulihan pada Atlet Sepak Bola SMA Negeri Keberbakatan Olahraga. 1-16. http://eprints.unm.ac.id/id/eprint/13697

Buckle, J. (2014). Clinical aromatherapy essential oil in healthcare (3rd ed.). Churchill Livingstone.

Craig. (2015). Aromatherapy.

Djilani, A., \& Dicko, A. (2012). The Therapeutic Benefits of Essential Oils. Nutrition, WellBeing and Health, February 2012. https://doi.org/10.5772/25344

Hafizudin, M., Subakti, S., \& Permadi, A. G. (2018). Pengaruh Sport Massage Terhadap Penurunan Denyut Nadi Recovery Atlet Futsal IKIP Mataram Tahun 2018. Jurnal IImiah Mandala Education, 4(1), 238. https://doi.org/10.36312/jime.v4i1.543

Irwanto, E., Santoso, D. A., T, B. S. M., Sandi, M., \& Mubin, D. (2021). Socialization and Training at Gloria Muda Volleyball Club. GANDRUNG, Jurnal Pengabdian Kepada Masyarakat, 2(1), 135-142.

Kholiqoh, B. (2017). Efek Aromaterapi Lavender Secara Evaporasi Terhadap Penurunan Tekanan Darah dan Denyut Jantung Pada Mahasiswa Fakultas Kedokteran Univeersitas Nahdlatul Ulama Surabaya. http://digilib.unusa.ac.id/data_pustaka19212.html

Laksana, B. D., Ugelta, S., \& Jajat. (2019). Recovery Kondisi Denyut Nadi dengan Joging dan Istirahat Dinamis. Jurnal Keolahragaan, 5(2), 12-19.

Lubis, L., Utami, N. V., \& Agustina. (2009). Effect of Lavender Essential Oil Aromatherapy on Recovery Time of Blood Pressure and Pulse Rate after Rhyming Test among Padjadjaran University Medical Students. 2, 1.

Lubis, R. F., \& Siregar, N. S. (2017). Pengaruh Pemberian Semangka Terhadap Denyut Nadi Pemulihan Setelah Melakukan Aktivitas Fisik. Sains Olahraga: Jurnal IImiah IImu Keolahragaan, 1(1), 1-10. https://doi.org/10.24114/so.v1i1.6127

Mehemed, K. K. (2014). Relationship Between Physical Activity, Fitness Level, Body Composition, and Coronary Heart Disease Risk Factors in Malaysians and Arab Adolescent Student [Universiti Putra Malaysia,]. https://hsgm.saglik.gov.tr/depo/birimler/saglikli-beslenme-hareketli-hayat$\mathrm{db} /$ Yayinlar/kitaplar/diger-kitaplar/TBSA-Beslenme-Yayini.pdf

Prima, I. G. A., \& Ap, D. (2013). Lavender Aromateraphy As a Relaxant. E-Jurnal Medika Udayana, 2(1), 21-53.

Pujiati, W., Nirnasari, M., Saribu, H. J. D., \& Daratullaila, D. (2019). Aromaterapi Kenanga Dibanding Lavender terhadap Nyeri Post Sectio Caesaria. Jurnal Keperawatan 
Edi Irwanto \& Arik Winarto | Reaksi Esensial Oil Lavender Pada Recovery Denyut Jantung Atlit Bolavoli UNIBAVIC

Silampari, 3(1), 257-270. https://doi.org/10.31539/jks.v3i1.534

Purwata. (2015). Kelelahan dan recovery dalam olahraga. Jurnal Pendidikan Kesehatan Rekreasi, 1, 2-13.

Ramadhan, M. R., \& Zettira, O. Z. (2017). Aromaterapi Bunga Lavender ( Lavandula angustifolia ) dalam Menurunkan Risiko Insomnia. Fakultas Kedokteran Universitas Lampung, 6, 60-63.

Reka, G., Sri, K., Basuki, W., Risanti, E. D., \& Hernawan, B. (2020). RUTINITAS OLAHRAGA ( Resting pulse and heart rate recovery influenced by routinly exercise ). 3(2012), 85-90.

Siahaan, R., Rahardjo, T. B., \& Ranti, A. (2014). Effectiveness of Indonesian Essential Oil Mixture of Lemongrass, Cananga, and Patchouli in Relaxation through Inhalation: A Clinical Test on Healthy Woman with High Potential for Stress. Makara Journal of Health Research, 18(3), 143-151. https://doi.org/10.7454/msk.v18i3.4377

Sugiyono. (2013). Metode penelitian pendidikan. Alfabeta.

Taware, G. B., Bhutkar, M. V., \& Surdi, A. D. (2013). A profile of fitness parameters and performance of volleyball players. Journal of Krishna Institute of Medical Sciences University, 2(2), 48-59.

Tias, R. F., \& Hidayat, M. M. (2018). Analisis dan Desain SiBIOS: Deteksi Dini Kondisi Jantung dan Peningkatan Kualitas Hidup Manusia. Techno.Com, 17(3), 312-322. https://doi.org/10.33633/tc.v17i3.1814

Wiarto, G. (2013). Fisiologi dan Olah Raga (1st ed.). Graha IImu.

Widiarti, A. W., \& Suhardi. (2015). Penurunan Kecemasan Menghadapi Skripsi Dengan Menggunakan Aromaterapi Inhalasi. Jurnal Terpadu IImu Kesehatan, 4(2), 82-196.

Wulansari, R. D. R. (2017). Pengaruh pemberian aromaterapi lavender terhadap tekanan darah pada penderita hipertensi [STIKES Insan Cendikia Medika]. https://www.oecd.org/dac/accountable-effective-institutions/Governance Notebook 2.6 Smoke.pdf 